\title{
Interrelationships of Blood Sugar and Ketones in Insulin-treated Diabetics*
}

\author{
P. J. WATKINS, $\dagger$ M.D., M.R.C.P. ; M. G. FITzGERALD, $\ddagger$ M.D., F.R.C.P. ; J. M. MALINS, $\ddagger$ M.D., F.R.c.P.
}

\author{
British Medical fournal, 1969, 4, 648-651
}

\begin{abstract}
Cummary : A survey of ketonuria in insulin-treated $S$ diabetics showed that its significance might vary according to the time of day at which the test was performed. Some of the patients had uncontrolled diabetes in the early morning, when severe hyperglycaemia and hyperketonaemia occurred together, whila later during the same day or night an episode of hypoglycaemia caused hyperketonaemia, indicating that too much insulin had been given. Ccrrect assessment of the significance of ketonuria is obviously important, because som: patients would probably require a decrease rather than an increase of insulin dosage. Ketonuria does not necessarily indicate impending ketoacidosis.
\end{abstract}

\section{Introduction}

The occurrence of intermittent ketonuria in apparently wellregulated diabetics has often been observed, but its true significance is obscure. This apparent anomaly provoked considerable curiosity after the introduction of insulin proved to be effective in abolishing ketosis. Control of diabetes by attention to ketonaemia has been suggested by some authorities (Krainick and Müller, 1938 ; Werk and Knowles, 1961), but nore have described how this should be done. Most patients are not in fact asked to test for ketonuria on account of the confusion which would occur. The significance of ketonuria in association with glycosuria is very different from that occurring in its absence, and advice to patients who discovered ketonuria would need to be complex and therefore unsatisfactory. The popular belief that the appearance of ketonuria indicates impending ketoacidosis is difficult to dispel.

Moderate hyperketonaemia has been described as a feature of many "controlled" diabetics (Werk and Knowles, 1961; Tassopoulos et al., 1969) and the breath acetone is of ten raised (Henderson et al., 1952). No correlation between the ketonaemia and blood sugar has been established, and they do not always increase or decrease simultaneously (Krainick and Müller, 1938 ; Poulsen, 1941 ; Werk and Knowles, 1961 ; Akerblom, 1965). Wide and rapid diurnal fluctuations of both ketonaemia and blood sugar have been demonstrated by all of these investigators, and for this reason little information is obtained from infrequent or single determinations. Moreover, many factors other than control of diabetes may affect levels of ketonaemia. These include duration of fasting, dietary fat and carbohydrate intake, exercise ( $\AA$ kerblom, 1965), and emotional stresses (Hinkle et al., 1950), and may complicate the interpretation of hyperketonaemia or ketonuria in random samples of blood or urine.

The present investigation was therefore undertaken to study the diurnal variations of both blood sugar and ketone bodies by performing determinations through the day and night to find their relationship to each other and to discover, if possible, the events which predispose to their elevation.

\section{Patients and Methods}

Patients showing frequent episodes of ketonuria ${ }^{1}$ at clinic attendances were selected for a retrospective study of its fre- quency and for the more detailed investigations described below. The criterion arbitrarily chosen for inclusion in this group was a minimum of six episodes of ketonuria not separated by more than four attendances without ketonuria. More detailed investigations of diurnal variations of blood sugar and $\beta$ hydroxybutyrate of seven patients treated with insulin in this group were undertaken. All these patients were in good health, were leading normal active lives, and were minimally inconvenienced by their diabetes. In addition, one patient who was well controlled with oral treatment was studied. The subjects were admitted to hospital on the evening before the test. They were ambulant, but rested in bed for at least five minutes before each blood sample was taken. Smoking was not allowed. Each patient chose his own diet so that it should match his usual habits as closely as possible. Venous blood samples were taken at hourly intervals during varying periods of day and night.

Blood sugars were determined by the ferricyanide AutoAnalyzer method. A modification (Gibbard and Watkins, 1968) of the enzymatic method originally described by Williamson et al. (1962) was used for the determination of blood $\beta$ hydroxybutyrate. ${ }^{2}$

\section{Results}

During one year there were 12,237 follow-up attendances at the diabetic clinic, and among these were 43 patients with frequent episodes of ketonuria (as defined above). A retrospective study of their records showed that ketonuria occurred in $52 \%$ of their total of 1,172 attendances at the diabetic clinic. Most of these patients ( $81 \%$ ) were under the age of 40 at diagnosis. Sixty-four per cent. of the urine samples showing ketonuria contained $2 \%$ sugar (Clinitest tablet test), but glycosuria was absent from $5 \%$ of samples with ketonuria. The phenomenon of intermittent ketonuria occurred throughout the diabetic life history of some patients, but began several years after diagnosis (average 5.9 years, maximum 28 years) in others and continued during periods of 1 to 12 years (average $7 \cdot 3$ years). Clinic records of such patients are shown in the captions of Figs. 2-7.

Diurnal Variations of Blood Sugar and Ketonaemia.-The results of the investigations on seven of the patients studied are shown in Figs. 2-7. The chlorpropamide-treated patient described in Fig. 1 shows blood $\beta$-hydroxybutyrate levels in the normal range (less than $0.1 \mathrm{mM}$ ) throughout the day, and is presented for comparison with the case descriptions which follow. The key to the figures accompanies the caption to Fig. 1.

\footnotetext{
* This work forms part of the dissertation for the Cambridge M.D. degree of P. J. Watkins.

† Senior Medical Registrar, the General Hospital, Birmingham 4. $¥$ Physician, the General Hospital, Birmingham 4 .

${ }^{1}$ Ketonuria was detected in random uxine samples by the Acetest tablet.

' $\beta$-hydroxybutyrate alone has generally been measured: though the ratio of $\beta$-hydroxybutyrate to acetoacetate is not constant, they always increase and decrease simultaneously (see Fig. 7).
} 


\section{Summary of Results}

(1) Episodes of hypoglycaemia (defined here as a blood-sugar level less than $50 \mathrm{mg} . / 100 \mathrm{ml}$.) occurred in five of the seven

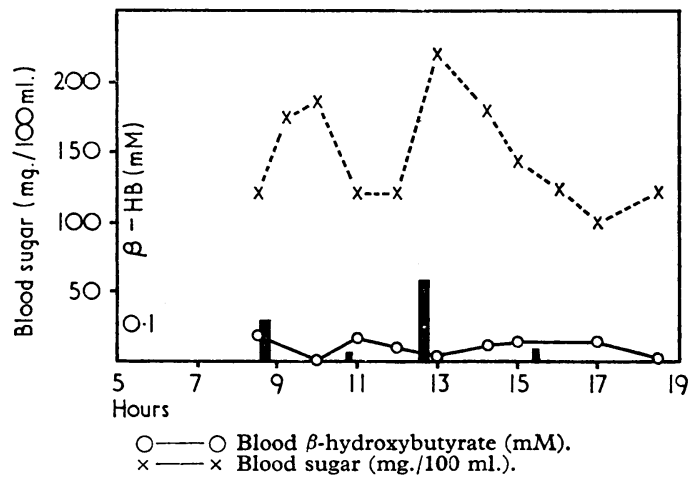

FIG. 1.-Man, aged 59. Diabetes diagnosed at age 54. Treated with chlorpropam de $250 \mathrm{mg}$. daily. In the Figures the vertical arrow indicates time of insulin administration and black bars indicate mealtimes. The carbohydrate content of each meal is read in grammes from the blood sugar scale.

patients described (Figs. 2-6), and two of these were recorded during the night (Figs. 3 and 5). A sharp increase of ketonaemia occurred while a low blood sugar persisted in every case. During these periods ketonuria was recorded in the absence of glycosuria (Figs. 2 and 3). The patient described in Fig. 6 was given $50 \mathrm{~g}$. of glucose orally after the injection of insulin, and thereafter was starved for the rest of the day. He became hypoglycaemic four and three-quarter hours later, and the striking increase in the ketonaemia occurred earlier than in the other patients treated with soluble insulin.

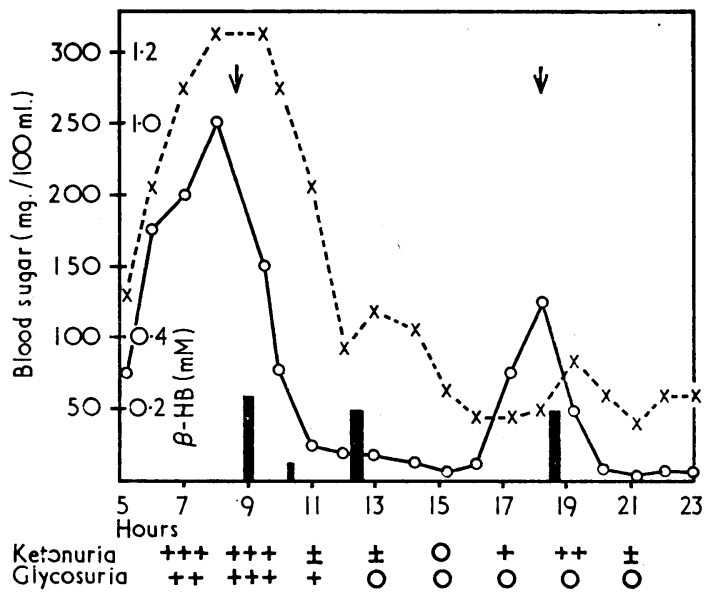

FIG. 2.-Man aged 30. Diabetes diagnosed at 13. Treated with soluble insulin 48 units mane, 36 units nocte. Frequent ketonuria observed during 15 years, occurring in 23 of the previous $48(48 \%)$ attendances.

\begin{tabular}{|c|c|c|c|c|c|c|}
\hline \multicolumn{2}{|c|}{$\begin{array}{l}\text { Random Urine } \\
\text { Sample: }\end{array}$} & \multirow{2}{*}{$\begin{array}{c}\begin{array}{l}\text { June } \\
1965\end{array} \\
++++ \\
+++\end{array}$} & \multirow{2}{*}{$\begin{array}{c}\begin{array}{c}\text { December } \\
1965\end{array} \\
++++ \\
+++\end{array}$} & \multirow{2}{*}{$\begin{array}{c}\begin{array}{c}\text { June } \\
1966\end{array} \\
\begin{array}{c}+++ \\
++\end{array}\end{array}$} & \multirow{2}{*}{$\begin{array}{c}\begin{array}{c}\text { December } \\
1966\end{array} \\
\begin{array}{c}+++ \\
++\end{array}\end{array}$} & \multirow{2}{*}{$-\frac{\begin{array}{c}\text { June } \\
1967\end{array}}{++++}$} \\
\hline $\begin{array}{l}\text { Glycosuria . . } \\
\text { Ketonuria . }\end{array}$ & $\therefore$ & & & & & \\
\hline \multicolumn{2}{|c|}{$\begin{array}{l}\text { Afternoon blood } \\
\text { sugar (mg./100 ml.) }\end{array}$} & 105 & 105 & 210 & 110 & 60 \\
\hline
\end{tabular}

(2) Rapid increases of both blood sugar and ketonaemia occurred in many of the patients during the hours before breakfast, sometimes achieving very high levels. Glycosuria and ketonuria occurred together during these periods.

(3) The administration of insulin followed by breakfast resulted in a rapid decrease of the ketonaemia in every case. This decrease often occurred earlier and more rapidly than that of the blood sugar, which sometimes continued to increase for a short period. Thus normal levels of ketonaemia were sometimes recorded while moderately severe hyperglycaemia persisted.

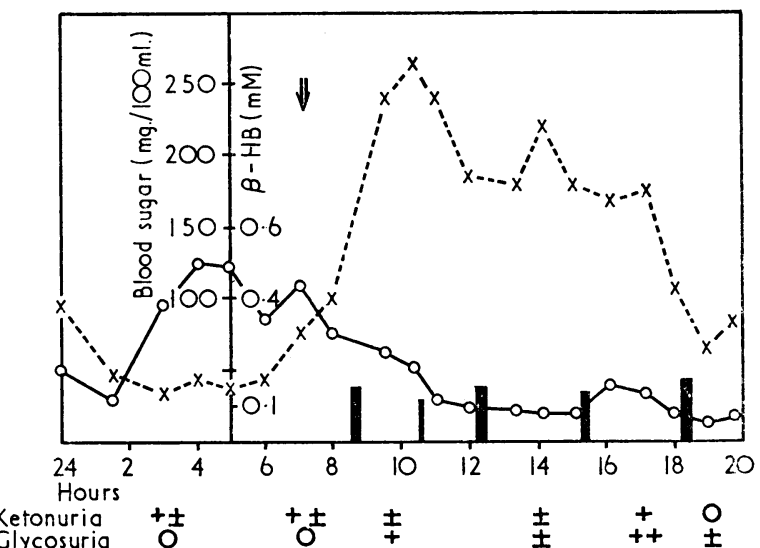

Fig. 3.-Man aged 53. Diabetes diagnosed at 39. Treated with insulin zinc suspension 60 units daily. Intermittent ketonuria observed since diagnosis, occurring in 15 of the previous $31(48 \%)$ attendances during 14 years. Rare mild hypoglycaemic reactions.

\begin{tabular}{|c|c|c|c|c|c|}
\hline $\begin{array}{l}\text { Random Urine } \\
\text { Sample: }\end{array}$ & $\underset{1964}{\text { January }}$ & $\begin{array}{c}\text { October } \\
1964\end{array}$ & $\begin{array}{l}\text { May } \\
1965\end{array}$ & $\underset{1966}{\text { January }}$ & $\underset{1967}{\operatorname{January}}$ \\
\hline $\begin{array}{ll}\text { Glycosuria } & \ldots\end{array}$ & $\begin{array}{l}++ \\
++\end{array}$ & $\begin{array}{c}+++ \\
+++\end{array}$ & $+\underset{0}{+}+$ & $\begin{array}{c}+++ \\
+\end{array}$ & $\begin{array}{c}++++ \\
+++\end{array}$ \\
\hline $\begin{array}{l}\text { Afternoon blood } \\
\text { sugar (mg. } / 100 \mathrm{ml} .)\end{array}$ & 185 & 235 & 180 & 195 & 295 \\
\hline
\end{tabular}

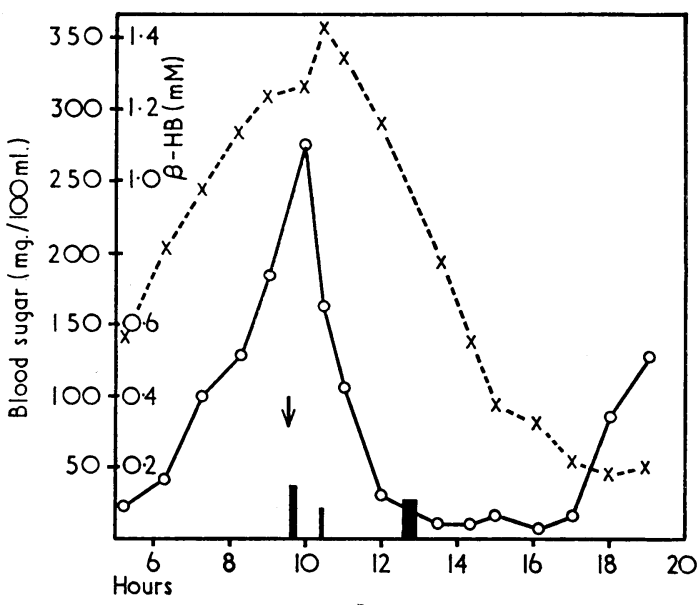

Fig. 4.-Woman aged 38. Diabetes diagnosed at 25 . Treated with soluble insulin 24 units mane, 20 units nocte. Intermittent ketonuria observed since diagnosis, occurring in 19 of $33(58 \%)$ attendance during

\begin{tabular}{|c|c|c|c|c|c|}
\hline $\begin{array}{l}\text { Random Urine } \\
\text { Sample: }\end{array}$ & $\begin{array}{l}\text { April } \\
1965\end{array}$ & $\begin{array}{l}\text { April } \\
1966\end{array}$ & $\begin{array}{l}\text { April } \\
1967\end{array}$ & $\begin{array}{l}\text { July } \\
1967\end{array}$ & $\begin{array}{l}\text { July } \\
1967\end{array}$ \\
\hline 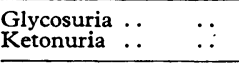 & $\begin{array}{c}++++ \\
+++ \\
\end{array}$ & $\begin{array}{l}0 \\
0\end{array}$ & $\begin{array}{c}+++ \\
++\end{array}$ & $\begin{array}{c}+++ \\
++\end{array}$ & $+\underset{0}{++}$ \\
\hline $\begin{array}{l}\text { Afternoon blood } \\
\text { sugar (mg./100 ml.) }\end{array}$ & 185 & 110 & 165 & 335 & 80 \\
\hline
\end{tabular}

\section{Discussion}

The occurrence of ketonuria in insulin-treated patients may indicate poorly controlled diabetes (Fig. 7), but it is sometimes misleading, and the present investigations have shown that its significance may alter at different times of the day. Thus a rapid parallel increase of both blood sugar and $\beta$-hydroxybutyrate concentrations of ten occurred during the hours before breakfast as the insulin action declined, and at this time ketonuria and glycosuria clearly indicated uncontrolled diabetes. The episodes of hypoglycaemia which occurred in some of these 
patients later during the same day or night were followed by a rapid increase of the ketonaemia while a low blood sugar persisted. During these periods ketonuria may be found in the absence of glycosuria (Figs. 2 and 3), thus occurring during a period of excessive insulin action. The appearance of ketonuria

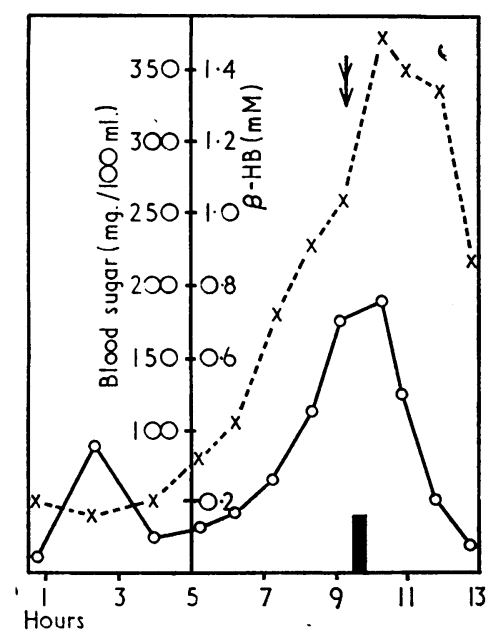

FIG. 5.-Girl aged 15. Diabetes diagnosed at 12 years. Treated with soluble insulin 32 units, isophane insulin 56 units daily. Intermittent ketonuria in 4 of $13(31 \%)$ attendances during three years.

\begin{tabular}{|c|c|c|c|c|c|}
\hline $\begin{array}{l}\text { Random Urine } \\
\text { Sample: }\end{array}$ & $\begin{array}{c}\text { October } \\
1966\end{array}$ & $\begin{array}{c}\text { November } \\
1966\end{array}$ & $\underset{1967}{\operatorname{January}}$ & $\begin{array}{l}\text { April } \\
1967\end{array}$ & $\begin{array}{l}\text { July } \\
1967\end{array}$ \\
\hline $\begin{array}{l}\text { Glycosuria } \ldots \\
\text { Ketonuria } \ldots\end{array}$ & $\stackrel{+}{0}$ & $\begin{array}{c}+++ \\
++\end{array}$ & $\begin{array}{c}+++ \\
+++\end{array}$ & $\begin{array}{l}\mathbf{0} \\
\mathbf{0}\end{array}$ & $\begin{array}{l}\mathbf{0} \\
\mathbf{0}\end{array}$ \\
\hline $\begin{array}{l}\text { Afternoon blood } \\
\text { sugar (mg./100 ml.) }\end{array}$ & 265 & 225 & 235 & 105 & 250 \\
\hline
\end{tabular}

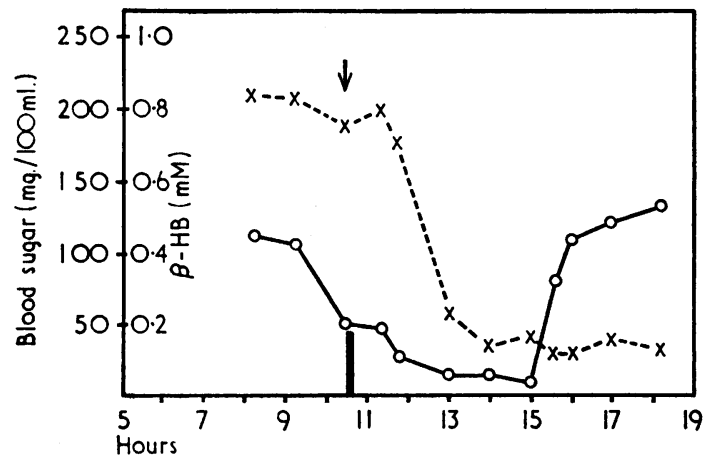
FIG. 6.- Man aged 26. Diabetes diagnosed at 20 . Treated with soluble
insulin 12 units and isophane insulin 48 units daily. On the day of the insulin 12 units and isophane insulin 48 units daily. On the day of the
experiment he received soluble insulin 32 units at 9.30 a.m. and $50 \mathrm{~g}$. experiment he received soluble insulin 32 units at 9.30 a.m. and $50 \mathrm{~g}$.
of oral glucose at $9.35 \mathrm{a} . \mathrm{m}$. instead of breakfast. Hypoglycaemic symptoms were first noticed at 2.15 p.m.

\begin{tabular}{|c|c|c|c|c|c|c|}
\hline \multicolumn{2}{|c|}{$\begin{array}{l}\text { Random Urine } \\
\text { Sample: }\end{array}$} & \multirow{2}{*}{$\frac{\begin{array}{c}\text { June } \\
1965\end{array}}{++++}$} & \multirow{2}{*}{$\begin{array}{c}\begin{array}{c}\text { December } \\
1965\end{array} \\
++ \\
++\end{array}$} & \multirow{2}{*}{ 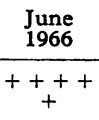 } & \multirow{2}{*}{ 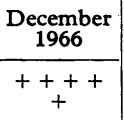 } & \multirow{2}{*}{$\begin{array}{c}\begin{array}{c}\text { January } \\
1967\end{array} \\
\begin{array}{c}++ \\
+++\end{array}\end{array}$} \\
\hline $\begin{array}{l}\text { Glycosuria } . . \\
\text { Ketonuria }\end{array}$ & $\because$ & & & & & \\
\hline $\begin{array}{l}\text { Afternoon b } \\
\text { sugar (mg. }\end{array}$ & & 160 & 180 & 190 & 110 & 255 \\
\hline
\end{tabular}

may therefore indicate poorly controlled diabetes or excessive insulin action, according to the time of day at which the test is performed. Hence its presence in random urine samples may be misinterpreted.

Asymptomatic hypoglycaemic episodes have often been described (Maddock and Trimble, 1928 ; Harrop, 1927 ; Joslin et al., 1959) and held responsible for the difficulty of diabetic control of some patients (Somogyi, 1959). Somogyi demonstrated the increase of glycosuria and appearance of ketonuria which may occur if the insulin dosage is increased. Though his conclusion that "hypoglycaemia begets hyperglycaemia" has not been fully substantiated (Chester et al., 1966) there is no doubt that patients in whom episodes of hypoglycaemia occur will not benefit from increase of the insulin dose. Reduction of insulin dosage and redistribution of diet may be important in order to eliminate the large swings of blood sugar and ketonaemia (Perkoff and Tyler, 1954 ; Goodman, 1955 ; Somogyi, 1959). The present work confirms that the hyperketonaemia (and therefore ketonuria) may indicate excessive insulin action at certain times of the day. The patients in whom this was demonstrated would probably have deteriorated if the insulin dosage had been increased, and this emphasizes the importance of the correct interpretation of ketonuria in the management of diabetes.

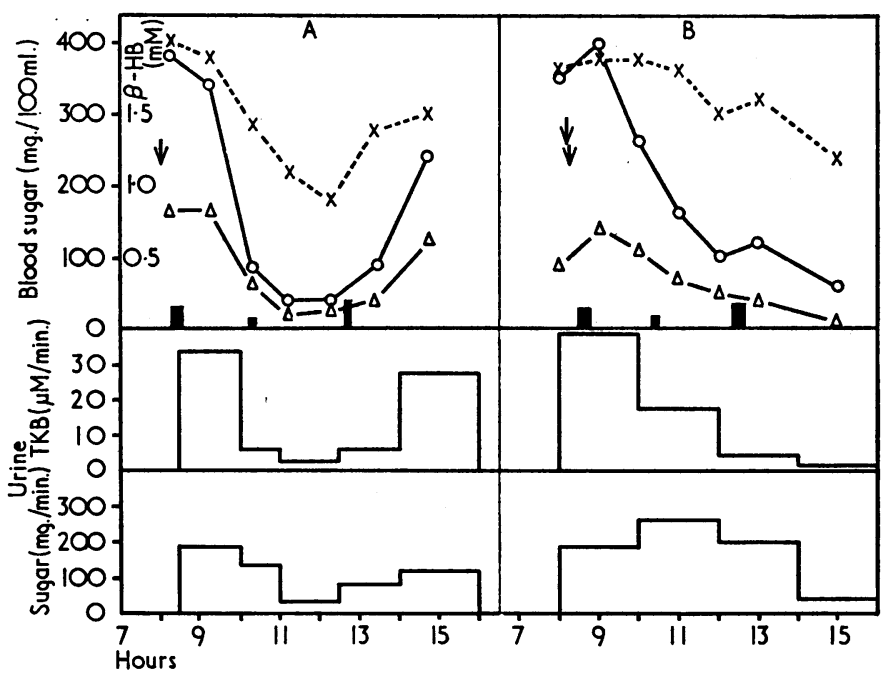

FIg. 7.-Case A. Woman aged 23. Diabetes diagnosed at 13. Treated with soluble insulin 14 units b.d. Intermittent ketonuria noted for seven years, occurring in 15 of $32(47 \%)$ attendances, and generally associated with poorly controlled diabetes. TKB $=$ Total ketone bodies. Case B. Woman aged 42. Diabetes diagnosed at 26. Treated with soluble insulin 24 units b.d., protamine zinc insulin 8 units mane. Intermittent ketonuria since diagnosis, occurring in 22 of $66(33 \%)$ attendances during 16 years.

The appearance of ketonuria following hypoglycaemia was first described soon after the introduction of insulin by Collip (1923) and later by Burn and Ling (1928). Subsequently Somogyi (1940, 1941) demonstrated the increased ketonaemia which follows hypoglycaemia. Ketonuria has also been described in cases of hypoglycaemia due to glycogen storage diseases (Hsia, 1964) and in infantile hypoglycaemia (Stephenson and Hainsworth, 1966). The ketogenic effect of hypoglycaemia has now been well established under carefully controlled experimental conditions, and the responsibility of the liver for the increased ketogenesis has been shown (McPherson et al., 1958 ; Amatruda et al., 1962).

Many theories have been advanced to explain the increased ketogenesis which follows hypoglycaemia. The release of several ketogenic hormones, including adrenaline, cortisol, and growth hormone, is known to occur in response to hypoglycaemia or even to a rapid fall of blood sugar. Amatruda et al. (1962), however, have shown that hyperketonaemia still follows hypoglycaemia in hypophysectomized and adrenalectomized animals, suggesting that these hormones are not responsible for this phenomenon. Release of catecholamines may be more important in this regard, but the evidence is not con- 
vincing. Though Houssay et al. (1967) showed that sympathectomy decreased the expected hyperketonaemia in pancreatectomized animals, and $\beta$-blockers such as propranolol are known to inhibit free fatty acid release (Abramson et al., 1966), others have shown that the ganglion blocker hexamethonium does not prevent the increase of hyperketonaemia or free fatty acids which follow hypoglycaemia (Werk et al., 1961).

Other mechanisms may be important in effecting these responses to hypoglycaemia. Relative insulin deficiency during hypoglycaemia has been suggested (Amatruda et al., 1962 ; Engel and Amatruda, 1963 ; Scow et al., 1964) but disputed by others (Armstrong et al., 1961). Glucagon release also follows hypoglycaemia, but its effect on ketogenesis is not well established (Penhos et al., 1966). Complex explanations may, however, be unnecessary, and decreased utilization of glucose which occurs if the blood glucose falls below the tissue threshold (Butterfield and Holling, 1959) may be solely responsible for this increased ketogenesis (Shreeve, 1963).

Ketonuria may also be misleading because it does not necessarily herald ketoacidosis. Relatively small rises in the blood ketone bodies may be associated with "strong" ketonuria as indicated by the currently used nitroprusside tests (Ketostix or the Acetest tablet), and the blood levels may be well below those which led to ketoacidosis. Huckabee (1961) thought that a total blood organic acid concentration of $5 \mathrm{mM}$ or more is required in order to alter the acid-base values, and it is clear from Fig. 2 and other work (Watkins and FitzGerald, 1968) that the ketonaemia may be very much less than this when "strong" ketonuria is present. Correct assessment of the significance of ketonuria can therefore be made only by determination of the blood ketone bodies. A semiquantitative estimation of plasma acetoacetate by use of Ketostix is adequate for this purpose (Watkins and FitzGerald, 1968), though more accurate automated determinations are now simple to perform (Salway, 1969).

The work was supported by grants from the Endowment Fund of the United Birmingham Hospitals and the British Diabetic Association. We are grateful for the help of Dr. R. Gaddie with biochemical aspects of the work and to Miss Maureen Betts for technical assistance.
REFERENCES

Abramson, E. A., Arky, R. A., and Woeber, K. A. (1966). Lancet, 2, 1386 .

Akerblom, H. (1965). Annales Paediatriae Fenniae, 11, Suppl. No. 25, p. 1 .

Amatruda, T. T., Chase, J. W., and Engel, F. L. (1962). Fournal of Clinical Investigation, $41,758$.

Armstrong, D. T., et al. (1961). American fournal of Physiology, 201, 535.

Burn, J. H., and Ling, H. W. (1928). Fournal of Physiology, 65, 191.

Butterfield, W. J. H., and Holling, H. E. (1959). Clinical Science, 18 147.

Chester, E. M., Travis, R. H., and Mackenzie, M. S. (1966). Diabetes, 15, 307.

Collip, J. B. (1923). Fournal of Biological Chemistry, 55, xxxviii.

Engel, F. L., and Amatruda, T. T. (1963). Annals of the New York Academy of Sciences, $104,753$.

Gibbard, S., and Watkins, P. J. (1968). Clinica Chimica Acta, 19, 511.

Goodman, J. I. (1955). American fournal of Medicine, 18, 448.

Harrop, G. A. (1927). Archives of Internal Medicine, 40, 216.

Henderson, M. J., Karger, B. A., and Wrenshall, G. A. (1952). Diabetes,

1, 188. Investigation, 29, 754 .

Houssay, B. A., et al. (1967). Diabetes, 16, 259.

Hsia, D. Y. (1964). In Diseases of Metabolism, 5th ed., edited by G. G. Duncan, p. 368. Philadelphia, Saunders.

Duncan, p. 368. Philadelphia, Saunders.
Huckabee, W. E. (1961). American fournal of Medicine, 30, 833.

Huckabee, W. E. (1961). American fournal of Medicine, 30, 833. The

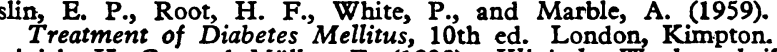

Treatment of Diabetes Mellitus, 10th ed. London, Kimpton.
Krainick, H. G., and Müller, F. (1938). Klinische Wochenschrift, 17, 1760 .

McPherson, H. T., Werk, E. E., Myers, J. D., and Engel, F. L. (1958) Fournal of Clinical Investigation, 37, 1379.

Maddock, S. J., and Trimble, H. C. (1928). fournal of the American Medical Association, 91, 616.

Penhos, J. C., Wu, C. H., Daunas, J., Reitman, M., and Levine, R. (1966). Diabetes, 15, 740 .

Perkoff, G. T., and Tyler, F. H. (1954). Metabolism, 3, 110.

Poulsen, J. E. (1941). Studies on the Ketosis in Diabetes Mellitus. Copenhagen, Busck.

Salway, J. G. (1969). Clinica Chimica Acta, 25, 109.

Scow, R. O., Chernick, S. S., and Brinley, M. S. (1964). American fournal of Physiology, 206, 796.

Shreeve, W. W. (1963). Annals of the New varb Arademy of Sciences, 104,772 .

Somogyi, M. (1940). Proceedings of the Soctety of Expertmenial Biology and Medicine, 45, 644.

Somogyi, M. (1941). fournal of Biological Chemistry, 141, 219.

Somogyi, M. (1959). American Fournal of Medicine, 26, 169.

Stephenson, J. B. P., and Hainsworth, I. R. (1966). Proceedings of the Association of Clinical Biochemists, 5,80 .

Tassopoulos, C. N., Barnett, D., and Fraser, T. R. (1969). Lancet, 1, 1282.

Watkins, P. J., and FitzGerald, M. G. (1968). Diabetes, 17, 398

Werk, E. E., Garber, S., and Sholiton, L. J. (1961). Metabolism, 10, 115.

Werk, E. E., jun., and Knowles, H. C., jun. (1961). Diabetes, 10, 22.

Williamson, D. H., Mellanby, J., and Krebs, H. A. (1962). Biochemical Fournal, 82, 90 .

\title{
Blood Pressure in a Scottish Island Community
}

\author{
V. M. HAWTHORNE,* M.D. ; C. R. GILLIS, † M.B., CH.B.; A. R. LORIMER, $\ddagger$ M.B., M.R.C.P.GLASG. \\ F. R. CALVERT, § M.B., CH.B., D.P.H. ; T. J. WALKER $\|$
}

British Medical fournal, 1969, 4, 651-654

\begin{abstract}
Summary : A survey of mean blood pressure levels in age-and-sex-matched samples of the population of the island of Tiree appears to support the local belief that blood pressure is higher on the island than on the mainland. This conclusion may be related to the observation of a greater mean width of the heart, measured radiologically, in the island population compared with the mainland population. The greater mean body weight observed in the island compared with the mainland may be a factor. Blood pressure in men between the ages of 40 and 59 years is higher in Tiree than in selected samples in England and America.
\end{abstract}

\section{Introduction}

Cardiovascular disease is the main cause of death in Scotland (Registrar General for Scotland, 1968). Since hypertension may be an important factor in determining risk (Epstein, 1965), a study of the prevalence of hypertension in the popu-

* Senior Lecturer in Epidemiology and Preventive Medicine, University of Glasgow.

† Lecturer in Epidemiology and Preventive Medicine, University of Glasgow.

$\ddagger$ Lecturer in Medical Cardiology, University of Glasgow.

5 General Practitioner, Island of Tiree.

II Science Student, University of Glasgow. 